\title{
Sources of Carbon and Energy used by Coprinus lagopus sensu Buller
}

\author{
By D. MOORE \\ Department of Botany, The University, Manchester, $M 139 P L$
}

(Accepted for publication I4 May 1969)

SUMMARY

\begin{abstract}
The sources of carbon + energy utilized by a strain of Coprinus lagopus which is in wide use in biochemical and genetic experiments have been determined. Over $\mathrm{I} 20$ compounds were tested for growth in liquid medium. Only acetate, fructose, glucose, maltose, mannitol, mannose, xylose and the polymers cellulose and starch supported growth as sole carbon + energy sources at Io mM concentration. Amino acids were used as sources of carbon, but only in the presence of equimolar amounts of glucose. Suggestive evidence was obtained for inducible enzyme systems concerned with the utilization of ethanol, lactose and alginate.
\end{abstract}

\section{INTRODUCTION}

The carbon nutrition of the Basidiomycete genus Coprinus has received attention from a number of workers in recent years (Leonian \& Lilly, 1938; Voderberg, 1948; Fries, 1955; Madelin, 1956a). For a variety of reasons, however, it was decided to repeat and extend some of what has already been done. There is reason to believe (Fries, I955; and see Discussion) that, with respect to nutrition in general, a good deal of polymorphism may occur among isolates of the same species. The nomenclature of Coprinus lagopus and its allies is considerably confused so that the identity of the material used in previous studies is strictly speaking uncertain. Also, most previous investigations have been particularly related to studies of fruiting behaviour, and have thus been mainly concerned with the physiology of the dikaryon. The present report lays emphasis on monokaryons of an isolate which is well characterized genetically (Day \& Anderson, I961; Moore, 1967), with the intention of providing a reliable basis for more detailed biochemical and genetical analyses of carbon metabolism.

\section{METHODS}

Organism. The strains used belonged to a backcrossed wild-type line prepared by D. H. Morgan from the strains originally isolated from the wild by P. R. Day (Day \& Anderson, 196I). They had the stock numbers $B C 9 / 66$ (mating type $A_{6} B_{6}$ ) and $\mathrm{BC} 9 / 55\left(\mathrm{~A}_{5} \mathrm{~B}_{5}\right)$ and were isolated after nine generations of backcrossing to Day's $\mathrm{H}_{9}$ wild type. These isolates agree extremely well with the description of Coprinus lagopus given by Buller (1924) and his example of the use of this name has been followed in many publications dealing with genetic phenomena in these strains (e.g. Day \& Anderson, I96ı; Morgan, I966; Cowan \& Lewis, I966; Casselton \& Lewis, I967; Moore, I967).

Media. The basal liquid medium (referred to as NCM) contained: $30 \mathrm{mM}-\mathrm{NH}_{4} \mathrm{Cl}$; 
Io $\mathrm{mM}-\mathrm{Na}_{2} \mathrm{HPO}_{4} ; \quad$ Io $\mathrm{mM}-\mathrm{KH}_{2} \mathrm{PO}_{4} ; \quad 2 \mathrm{mM}-\mathrm{Na}_{2} \mathrm{SO}_{4} ; \mathrm{I} \cdot 5 \times 10^{-6} \mathrm{M}$-thiamine hydrochloride; no trace elements were added to this medium. The medium was at pH 6.8 after autoclaving for $\mathrm{IO} \mathrm{min}$. at $\mathrm{I} 2 \mathrm{I}^{\circ}$. Substances tested for availability as sole sources of carbon+energy originated from commercial firms; most were added in the solid form to the basal medium immediately before sterilization. All carbohydrates, labile and volatile substances were added as filter-sterilized solutions to appropriately concentrated sterile NCM. Unless otherwise stated all potential carbon + energy sources were added to a final concentration of $10 \mathrm{~mm}$. Tests involving sparingly soluble substances essentially involved saturated solutions. Polymers were used at the rate of $\mathrm{I} \cdot 8 \mathrm{mg} . / \mathrm{ml}$.

Inocula were $2 \mathrm{~mm}$. diameter discs cut from the margins of 6-day colonies growing on NCM $+5 \mathrm{~mm}$-glucose. The mycelial discs were cut $24 \mathrm{hr}$ before use and incubated at $37^{\circ}$ until used on Coprinus complete medium (Moore, 1968). This period of incubation resulted in the production of a small amount of fresh aerial mycelium which considerably eased the task of floating inocula onto the liquid medium surface (Norkrans, 1953).

Cultivation in liquid medium. The liquid media were used in $20 \mathrm{ml}$. quantities in $9 \mathrm{~cm}$. glass Petri plates. A single inoculum disc was floated on each and the plates incubated statically at $37^{\circ}$ for 14 days. Five such plates (i.e. a total of $100 \mathrm{ml}$. medium +5 inoculum discs) constituted a single test; five replicates of each test were generally made.

Harvesting was done by filtration through weighed Oxoid membrane filters, the harvest being washed with $200 \mathrm{ml}$. of cold water during filtration. Sparingly soluble compounds were removed by repeated washings with large volumes of warm water. The membranes and harvest were dried to constant weight at $40^{\circ}$.

\section{RESULTS AND DISCUSSION}

The response of the haploid wild-type monokaryon, $\mathrm{BC} 9 / 66$, to the compounds tested individually as carbon + energy sources is summarized in Tables $I$ and 2. Although at least some variation in mycelial yield was evident in tests involving utilizable compounds there was an unmistakable and consistent difference between substances which were not utilized and those that were used either well or weakly. Of the I 24 compounds tested as sole sources of carbon + energy only eight were used by this organism at $10 \mathrm{mM}$ concentrations.

A comparison of the yields of mycelium obtained from the monokaryons $\mathrm{BC} 9 / 66$ and $\mathrm{BC} / 55$ and their joint dikaryon on a selection of potential carbon + energy sources is shown in Table 3. These figures, and the data in subsequent Tables, come from experiments in which attention was concentrated on a much more limited selection of compounds than was used in the initial screening tests.

The BC9/66 monokaryon was tested for growth on different concentrations of some potential carbon + energy sources (Table $4 a$ ) and the growth of all three mycelia compared on different glucose concentrations (Table $4 b$ ). It was evident from these experiments that lactose, and possible sucrose, though classified as not utilized in the initial screening tests, could nevertheless support at least some growth at high concentrations. Attempts were therefore made to see whether growth could be obtained on these and related compounds in supplemented media. 
Table I. Compounds which did not support the growth of Coprinus

lagopus BC9/66 when present as sole source of carbon +energy

(i) Sugars and related compounds

$\begin{array}{lll}\text { Alginate } & \text { Glucose-6-phosphate } & \text { Mucate } \\ \text { D-arabinose } & \text { 2-deoxy-D-glucose } & \text { Raffinose } \\ \text { L-arabinose } & \text { Glucuronate } & \text { Rhamnose } \\ \text { Ascorbate } & \text { Glycerol } & \text { Ribose } \\ \text { Dihydroxyacetone } & \text { Inositol } & \text { Sorbose } \\ \text { Galactose } & \text { Lactose } & \text { Stachyose } \\ \text { Glucosamine } & \text { Melibiose } & \text { Sucrose }\end{array}$

(ii) Amino acids and related compounds

$\begin{array}{lll}\text { L-alanine } & \text { L-glutamine } & \text { L-ornithine } \\ \text { L-arginine } & \text { Glycine } & \text { L-phenylalanine } \\ \text { L-asparagine } & \text { Glycylglycine } & \text { L-proline } \\ \text { L-aspartate } & \text { L-histidine } & \text { L-serine } \\ \text { Creatine } & \text { L-hydroxyproline } & \text { L-threonine } \\ \text { L-cysteine } & \text { L-leucine } & \text { L-tryptophan } \\ \text { L-cystine } & \text { L-isoleucine } & \text { L-tyrosine } \\ \text { L-glutamate } & \text { L-lysine } & \text { L-valine } \\ & \text { L-methionine } & \end{array}$

(iii) Normal alcohols, mono- and dicarboxylic acids

$\begin{array}{lll}\text { Methanol } & \text { Formate } & \\ \text { Ethanol } & & \text { Oxalate } \\ \text { Propanol } & \text { Propionate } & \text { Malonate } \\ \text { Butanol } & \text { Butyrate } & \text { Succinate } \\ \text { Pentanol } & \text { Valerate } & \text { Glutarate } \\ \text { Hexanol } & \text { Caproate } & \text { Adipate }\end{array}$

(iv) Aliphatic and related compounds

\begin{tabular}{|c|c|c|}
\hline Acetaldehyde & Ethyl acetate & Linolenate \\
\hline Acetone & Fumarate & Malate \\
\hline Aconitate & D,L-glycorate & Maleate \\
\hline Acrylamide & Glycollate & Oxalacetate \\
\hline Isobutanol & Glyoxylate & 2-oxoglutarate \\
\hline Citrate & Lactate & Isopropanol \\
\hline Isocitrate & Linoleate & Pyruvate \\
\hline Ethanolamine & & Tartrate \\
\hline \multicolumn{3}{|c|}{ (v) Aromatic compounds } \\
\hline Benzaldehyde & Benzyl alcohol & Phenol \\
\hline Benzoate & D-mandelate & Phenylpyruvate \\
\hline
\end{tabular}

(vi) Purines, Pyrimidines and derivatives

$\begin{array}{lll}\text { Adenine } & \text { DNA (thymus) } & \text { Thymine } \\ \text { Allantoin } & \text { Guanine } & \text { Uracil } \\ \text { Cytosine } & \text { Hypoxanthine } & \text { Urea } \\ \text { 5-methylcytosine } & \text { Inosine } & \text { Xanthine } \\ & \text { RNA (yeast) } & \end{array}$

(vii) Heterocyclic, alicyclic and related compounds

$\begin{array}{lll}\text { Biotin } & \text { Nicotinamide } & \text { Pyridoxine } \\ \text { Folate } & \text { Nicotinate } & \text { Quinate } \\ \text { Indole } & & \text { Thiamine }\end{array}$

Experiments with the $\mathrm{BC} 9 / 66$ monokaryon and testing for growth on $\mathrm{NCM}+\mathrm{I} O \mathrm{mM}$ glucose + Io mM test carbon source (Table 5) showed that many of the compounds which did not support growth when present as sole sources of carbon +energy also 
failed to support growth when mixed with equimolar glucose. On the other hand some compounds did show a significant synergistic response. This pattern was also evident with a medium consisting of NCM + yeast extract + vitamin mixture + trace elements which could reasonably be supposed to contain any additive whose absence from the basal medium might restrict utilization (Table 6).

Table 2. Compounds utilized as sole source of carbon + energy by Coprinus lagopus $B C 9 / 66$

Incubation: 14 days at $37^{\circ}$

$\begin{array}{cc}\text { Carbon source } & \begin{array}{r}\text { Mycelial dry weight } \\ \text { (mg./ } 100 \mathrm{ml} .)\end{array} \\ \text { NCM } & 3 \cdot 4 \pm 0 \cdot 6 \\ \text { (no carbon source) } & \\ \text { Acetate } & 7 \cdot 4 \pm 2 \cdot 8 \\ \text { Cellulose } & 22 \cdot 3 \pm 2 \cdot 6 \\ \text { Fructose } & 22 \cdot 3 \pm 1 \cdot 8 \\ \text { Glucose } & 38 \cdot 1 \pm 2 \cdot 4 \\ \text { Maltose } & 22 \cdot 8 \pm 2 \cdot 0 \\ \text { Mannitol } & 19 \cdot 7 \pm 2 \cdot 2 \\ \text { Mannose } & 15 \cdot 2 \pm \mathrm{I} \cdot 7 \\ \text { Starch } & 17 \cdot 3 \pm \mathrm{I} \cdot 9 \\ \text { Xylose } & 12 \cdot 8 \pm \mathrm{I} \cdot 2\end{array}$

Table 3. Comparison of the growth of Coprinus lagopus BC9/66 and BC9/55 monokaryons and their joint dikaryon on selected carbon sources

Incubation: 14 days at $37^{\circ}$

\begin{tabular}{|c|c|c|c|}
\hline \multirow[b]{2}{*}{ Carbon source } & \multicolumn{3}{|c|}{ Mycelial dry weight $(\mathrm{mg} / 100 \mathrm{ml}$ ) } \\
\hline & $\mathrm{BC} 9 / 66$ & $\mathrm{BC} 9 / 55$ & Dikaryon \\
\hline $\begin{array}{l}\mathrm{NCM} \\
\text { (no carbon source) }\end{array}$ & $3.4 \pm 0.6$ & $2 \cdot 0 \pm 0 \cdot 9$ & $2 \cdot 7 \pm 0.8$ \\
\hline Acetate & $7 \cdot 4 \pm 2 \cdot 8$ & $7 \cdot 9 \pm 2 \cdot 5$ & $7 \cdot 2 \pm 1 \cdot 9$ \\
\hline L-alanine & $3.0 \pm 0.5$ & 0.4 & $3.8 \pm 0.5$ \\
\hline D-arabinose & 0.4 & $2.9 \pm 0.6$ & $3 \cdot 6 \pm 0.8$ \\
\hline Asparagine & $5 \cdot 9 \pm 2 \cdot 7$ & $2.9 \pm 0.5$ & $3 \cdot 9 \pm 2 \cdot 5$ \\
\hline Benzoate & $1 \cdot 3 \pm 0 \cdot 6$ & $3 \cdot 0 \pm 0 \cdot 7$ & $2.4 \pm 0.5$ \\
\hline Fructose & $22 \cdot 3 \pm I \cdot 8$ & $23 \cdot 0 \pm I \cdot 2$ & $28 \cdot 0 \pm 2 \cdot I$ \\
\hline Glucose & $38 \cdot 1 \pm 2 \cdot 4$ & $37 \cdot 9 \pm 3 \cdot I$ & $39 \cdot 2 \pm 3 \cdot 2$ \\
\hline Glycine & $0 \cdot 8$ & $1.6 \pm 0.3$ & $3.9 \pm 0.6$ \\
\hline Lactose & $2 \cdot 4 \pm 0.3$ & $2 \cdot 8 \pm 0.8$ & $3 \cdot 6 \pm 0 \cdot 9$ \\
\hline Lysine & 0.4 & $I \cdot 6 \pm 0 \cdot I$ & $2 \cdot I \pm 0 \cdot 2$ \\
\hline Maltose & $22 \cdot 8 \pm 2 \cdot 0$ & $25 \cdot 3 \pm 3 \cdot 0$ & $24 \cdot 0 \pm 2 \cdot 4$ \\
\hline Nicotinate & $2 \cdot 9 \pm 0.2$ & $3.8 \pm 0.8$ & $5 \cdot 8 \pm I \cdot 2$ \\
\hline RNA (yeast) & $3 \cdot 9 \pm 0.9$ & $3 \cdot I \pm 0.5$ & $2 \cdot 2 \pm 0.4$ \\
\hline Succinate & $I \cdot 4 \pm 0.7$ & $2 \cdot 8 \pm 0.3$ & $2 \cdot 2 \pm 0.4$ \\
\hline Sucrose & $I \cdot 9 \pm 0.3$ & $I \cdot 7 \pm 0.3$ & $2 \cdot 0 \pm 0.8$ \\
\hline Tyrosine & 0.2 & $2 \cdot 0 \pm 0.1$ & $2 \cdot 1 \pm 0 \cdot 7$ \\
\hline
\end{tabular}

Although only eight of the I 24 compounds initially tested served as sole carbon + energy sources (Table 2) it remains likely that wider screening or the use of different basal media and growth conditions would reveal additional compounds able to support growth. A particular difficulty with experiments such as these is, of course, that it is not known whether some of the compounds may have failed to support growth 
because of inability to act as inducers for the appropriate enzymes, or because of their not being transported into the cell.

Such difficulties apart, there is a clear indication that the Coprinus lagopus monokaryon $\mathrm{BC} 9 / 66$ was extremely restricted in the number of compounds it would accept

\section{Table 4. Effect of different initial concentrations of some potential carbon sources on the growth of Coprinus lagopus}

Incubation: 14 days at $37^{\circ}$

(a) Growth of the $\mathrm{BC} 9 / 66$ monokaryon

\begin{tabular}{|c|c|c|c|c|c|c|}
\hline & \multicolumn{6}{|c|}{ Substrate concentration (mM) } \\
\hline & $\mathbf{I}$ & 3 & 10 & 30 & 100 & 300 \\
\hline \multicolumn{7}{|c|}{ Mycelial dry we } \\
\hline Acetate & $3 \cdot 2$ & $4 \cdot 0$ & $8 \cdot 2$ & $15 \cdot 8$ & $29 \cdot 4$ & 0.2 \\
\hline Benzoate & 0.9 & $3 \cdot I$ & $2 \cdot 3$ & $2 \cdot 1$ & $3 \cdot I$ & $I \cdot I$ \\
\hline Fructose & $14 \cdot 4$ & 18.4 & $26 \cdot 5$ & $52 \cdot 0$ & $66 \cdot 7$ & $79 \cdot 5$ \\
\hline Galactose & 0.8 & $1 \cdot 2$ & $1 \cdot \mathbf{I}$ & $I \cdot 6$ & $I \cdot 0$ & $I \cdot 5$ \\
\hline Glucose & $10 \cdot 7$ & $12 \cdot 2$ & $40 \cdot 5$ & $106 \cdot 0$ & 120.5 & I 24.6 \\
\hline Lactose & $2 \cdot 6$ & $3 \cdot 9$ & $3 \cdot 5$ & $6 \cdot 0$ & 9.5 & $13 \cdot 2$ \\
\hline Raffinose & $I \cdot 9$ & 0.4 & $3 \cdot 2$ & 0.8 & $2 \cdot 3$ & $3 \cdot 0$ \\
\hline Sorbose & $2 \cdot 4$ & 0.5 & $1 \cdot 9$ & 0.9 & $1 \cdot 3$ & $2 \cdot 3$ \\
\hline Succinate & $2 \cdot 1$ & $I \cdot I$ & $I \cdot 4$ & 0.6 & $I \cdot 9$ & $1 \cdot 3$ \\
\hline Sucrose & $2 \cdot 4$ & $2 \cdot 5$ & $2 \cdot 6$ & $3 \cdot 3$ & $2 \cdot 2$ & $40 \cdot 7$ \\
\hline
\end{tabular}

(b) Growth of the $\mathrm{BC} / 66$ and $\mathrm{BC} / 55$ monokaryons and their joint dikaryon on different initial glucose concentrations

$\begin{array}{lrrrrrr}\mathrm{BC} 9 / 66 & 10 \cdot 3 & 19 \cdot 0 & 36 \cdot 4 & 99 \cdot 6 & 121 \cdot 0 & 120 \cdot 4 \\ \mathrm{BC} 9 / 55 & 2 \cdot 0 & 9 \cdot 6 & 35 \cdot 6 & 84 \cdot 2 & 98 \cdot 4 & 109 \cdot 8 \\ \text { Dikaryon } & 2 \cdot 2 & 13 \cdot 0 & 35 \cdot \mathrm{I} & 88 \cdot 9 & 104 \cdot 6 & 1 \mathrm{I} 4 \cdot 3\end{array}$

Table 5. Growth of Coprinus lagopus BC9/66 on some potential carbon sources in medium also containing $10 \mathrm{mM}$ glucose

Incubation: 14 days at $37^{\circ}$

$\begin{array}{cccc}\text { Carbon source added } & \begin{array}{c}\text { Mycelial dry weight } \\ (\mathrm{mg} .100 \mathrm{ml} .)\end{array} & \text { Carbon source added } & \begin{array}{c}\text { Mycelial dry weight } \\ (\mathrm{mg} .100 \mathrm{ml} .)\end{array} \\ \text { No addition* } & 38 \cdot \mathrm{I} \pm 2 \cdot 4 & \text { Galactose } & 41 \cdot 4 \pm 2 \cdot \mathrm{I} \\ \text { Adenine } & 5 \cdot 4 \pm 0 \cdot 8 & \text { Lactose } & 65 \cdot 3 \pm 2 \cdot 2 \dagger \\ \text { Acetate } & 53 \cdot 0 \pm \mathrm{I} \cdot 9 \dagger & \text { Maltose } & 77 \cdot 5 \pm 4 \cdot 3 \\ \text { Alanine } & 65.4 \pm 1 \cdot 5 \dagger & \text { Phenylalanine } & 57 \cdot 0 \pm 4 \cdot 7 \dagger \\ \text { Asparagine } & 78 \cdot 0 \pm \mathrm{I} \cdot \mathrm{I} \dagger & \text { Raffinose } & 44 \cdot 9 \pm 7 \cdot \mathrm{I} \\ \text { Benzoate } & 4 \cdot 0 \pm 1 \cdot 0 & \text { Serine } & 54 \cdot 7 \pm \mathrm{I} \cdot \mathrm{I} \dagger \\ \text { Citrate } & \mathrm{I} 6 \cdot 6 \pm \mathrm{I} \cdot 4 & \text { Sorbose } & 42 \cdot 4 \pm 5 \cdot 2 \\ \text { Ethanol } & 70 \cdot 5 \pm 9 \cdot 3 \dagger & \text { Succinate } & 37 \cdot 5 \pm 3 \cdot 1 \\ \text { Fructose } & 76 \cdot 0 \pm 3 \cdot 4 & \text { Sucrose } & 25 \cdot 5 \pm 2 \cdot 2\end{array}$

* 'No addition' in this Table $=\mathrm{NCM}+10 \mathrm{mM}$ glucose; all other carbon sources also added to $10 \mathrm{~mm}$ concentration.

$\uparrow$ Signifies a significant synergistic response.

as sole carbon + energy source. It was also quite clear that there was no very significant difference between the response patterns of the two monokaryons and their joint dikaryon. Madelin (I956a) reported C. lagopus to be cellulolytic and Fries (I955) suggested that Coprinus species which are strongly coprophilic are capable of decom- 
posing both cellulose and lignin. Since the strain under test here is indeed strongly coprophilic and was able to use cellulose, it is not surprising that the compounds which were most effectively used as sole carbon sources were closely related to these polymers.

The results presented here are in fair agreement with those reported by Madelin (1956a) for Coprinus lagopus and Fries (1955) for various Coprinus species. Chang ( 1967 ) reported an isolate of $C$. cinereus which was able to utilize cellobiose, cellulose, glucose, mannose, xylan and xylose. Some differences between the results of the present and previous studies are evident. Madelin (I956a) found a small but significant

Table 6. Effect of some potential carbon sources on the growth of Coprinus lagopus BC9/66 in fully supplemented medium

\begin{tabular}{|c|c|c|c|}
\hline \multicolumn{4}{|c|}{ Incubation: 14 days at $37^{\circ}$} \\
\hline Carbon source added & $\begin{array}{l}\text { Mycelial dry weight } \\
\text { (mg./100 ml.) }\end{array}$ & Carbon source added & $\begin{array}{l}\text { Mycelial dry weight } \\
\text { (mg./100 ml.) }\end{array}$ \\
\hline SNCM* & $43 \cdot 3 \pm 4 \cdot 9$ & Glucose & $185 \cdot 0 \pm 5 \cdot 1 \dagger$ \\
\hline Acetato & $67 \cdot 9 \pm 5 \cdot 9+$ & Lactose & $140.9 \pm 4.3 \dagger$ \\
\hline Alginate & $10 \mathrm{I} \cdot 5 \pm \mathrm{I} \cdot 2 \dagger$ & Maltose & $123.8 \pm 6.4 \dagger$ \\
\hline Arabinose & $67 \cdot 1 \pm 7 \cdot 5 t$ & Nicotinamide & $42 \cdot 9 \pm 5 \cdot 7$ \\
\hline Asparagine & $140 \cdot 2 \pm 4.9 \dagger$ & Raffinose & $54 \cdot 3 \pm 3 \cdot 2$ \\
\hline Benzoate & $29 \cdot 4 \pm 5 \cdot 1$ & Sorbose & $43 \cdot \mathrm{I} \pm \mathrm{I} \cdot 7$ \\
\hline Fructose & $171 \cdot 2 \pm 1 \cdot 0 \dagger$ & Succinate & $4 I \cdot 0 \pm 5 \cdot 7$ \\
\hline Galactose & $5 I \cdot 4 \pm 4 \cdot 7$ & Sucrose & $5 I \cdot 8 \pm 4 \cdot 7$ \\
\hline
\end{tabular}

$* \mathrm{SNCM}=\mathrm{NCM}+$ yeast extract $(0.07 \%, \mathrm{w} v)+$ vitamin mixture + trace elements. $\dagger$ Indicates a significant increase in growth.

amount of growth with glycerol and with alanine: this was not confirmed in the present work. However, it should be noted that Madelin used higher concentrations of individual carbon sources and a different basal medium. Certainly, alanine supported very vigorous growth of the $\mathrm{BC} 9 / 66$ monokaryon when mixed with glucose (Table 5). Other differences also became obvious during the present experiments. In particular, strains $\mathrm{BC}_{9} / 66$ and its relatives grew well with ammonium-nitrogen or asparaginenitrogen, and fairly well, although the growth was very variable, on nitrate-nitrogen. Madelin (I956a) reported his strain of $C$. lagopus to show little or no growth with nitrate or asparagine as sole nitrogen source, though it would utilize ammoniumnitrogen or alanine-nitrogen. It should, perhaps, be emphasized here that Madelin states that his isolate agreed well with Buller's (1924) description of C. lagopus, and the strains used in the present work also agree well with that description. However, Madelin used solid media as against the liquid medium used here, and more significantly the strain used by him had a temperature optimum of 20 to $25^{\circ}$ (Madelin, $\mathrm{I} 956 \mathrm{~b}$ ) as compared with a temperature optimum of $37^{\circ}$ for the $\mathrm{BC} 9 / 66$ monokaryon and its relatives. The list of discrepancies appearing in the literature on the nutrition of $C$. lagopus can be further extended. Voderberg (1948) reported her strain of C. lagopus as being able to utilize nitrate-, ammonium- or organic-nitrogen, but as requiring the presence of powdered straw for the utilization of simple carbohydrates. On the other hand, the C. lagopus studied by Leonian \& Lilly (1938) readily utilized glucose as sole carbon + energy source and amino acids as nitrogen source, though it was incapable of making use of either nitrate- or ammonium-nitrogen. It is thus quite evident that if these various isolates are indeed identical then either very considerable 
differences exist between the strains or the organism is extremely sensitive to alterations in cultural conditions. Conflicting findings such as these, taken together with the taxonomic difficulties previously noted, emphasize the necessity for adequate characterization of the nutritional versatility of each isolate.

Defined media containing a single carbon source are an inadequate representation of the conditions likely to be met by the fungus in nature. Growth in mixtures of substrates, though still a compromise, is more likely to give a true indication of the metabolic versatility of the organism. In the presence of glucose this organism showed considerable growth with a number of compounds not otherwise utilized as sole carbon sources (Table 5). The majority of such responses are most easily explained in terms of sparing reactions. Evidently the provision of an alternative initial source of energy, in the form of glucose, enabled amino acids to be accepted into the metabolic sequence and their carbon skeletons utilized. Stimulation of growth by the extra nitrogen offered by the amino acids is insufficient to account for the extent of the response seen. An active and probably inducible enzyme system for the utilization of ethanol is indicated by the response to that compound. An inducible enzyme system is also indicated (Tables 5, 6) for the utilization of alginate (polymannuronate) and of lactose. Galactose was definitely not used either as sole carbon source (Tables I, 4) or in supplemented media (Tables 5,6). Madelin (1956a) reported lactose and galactose to be inhibitory to the growth of his Coprinus lagopus. This was certainly not the case with the $\mathrm{BC} / 66$ monokaryon used here. Another distinction is that Madelin obtained an increase in growth by the addition of galactose to glucose-containing medium, though lactose retained some inhibitory properties in glucose medium. These results should be compared with those summarized in Tables 4, 5, 6 above. The position of sucrose is uncertain. None of the Coprinus species tested by Fries (I955) responded to 'saccharose' and Madelin (1956a) reported no growth of his C. lagopus with this disaccharide. Significant growth was obtained repeatedly in my experiments on the highest sucrose concentration tested ( $300 \mathrm{mM}$; Table $4 a$ ) though not in supplemented media with sucrose at $10 \mathrm{~mm}$ (Tables 5,6 ). The reason for this pattern of response is unclear. It is most likely that the sucrose was contaminated by free hexose, this only becoming significant at the high concentrations used in the experiments summarized in Table 4 . It would only require about $\mathrm{I}-2 \%$ contamination by hexose to give the mycelial yields obtained.

The skilful technical assistance of Miss C. Elizabeth Callan is gratefully acknowledged.

\section{REFERENCES}

Buller, A. H. R. (1924). Researches on Fungi, vol. 3. London: Longman, Grøen \& Co.

Casselton, L. A. \& LeWIS, D. (1967). Dilution of gene products in the cytoplasm of heterokaryons in Coprinus lagopus. Genet. Res. 9, 63.

CHANG, Y. (1967). The fungi of wheat straw compost. II. Biochemical and physiological studies. Trans. Br. mycol. Soc. 50, 667.

Cowan, J. \& LEwIS, D. (1966). Somatic recombination in the dikaryon of Coprinus lagopus. Genet. Res. 7, 235.

Day, P. R. \& Anderson, G. E. (1961). Two linkage groups in Coprinus lagopus. Genet. Res. 2 , 414.

FrIES, L. (1955). Studies in the physiology of Coprinus. I. Growth substance, nitrogen and carbon requirements. Svensk bot. Tidskr. 49, 475 . 
Leonian, L. H. \& Lilly, V. G. (1938). Studies on the nutrition of fungi. I. Thiamin, its constituents, and the source of nitrogen. Phytopathology 28, $53 \mathrm{I}$.

Madelin, M. F. (I956a). Studies on the nutrition of Coprinus lagopus Fr., especially as affecting fruiting. Ann. Bot. (N.S.) 20, 307.

MADELIN, M. F. (1956b). The influence of light and temperature on fruiting of Coprinus lagopus Fr. in pure culture. Ann. Bot. (N.S.) 20, 467.

MoORE, D. (I967). Four new linkage groups in Coprinus lagopus. Genet. Res. 9, $33 \mathrm{I}$.

MOORE, D. (I968). The effect of 2-deoxy-D-glucose on the growth and respiration of Coprinus lagopus. J. gen. Microbiol. 52, 433 .

MoRGaN, D. H. (I966). Suppression of 'purple' in Coprinus lagopus-an anomalous genetic situation. Genet. Res. 7, 195.

NorKRANS, B. (1953). The effect of glutamic acid, aspartic acid and related compounds on the growth of certain Tricholoma species. Physiol. Pl. 6, 584.

VODERBERG, K. (1948). Zum Nähr- und Wirkstoffbedarf von Coprinus lagopus. Z. Naturf. B 36, 272. 